\title{
Index of Subjects
}

ACTH treatment, milk, effect on citrate:lactoferrin concentrations, 379

Amino acids, uptake, mammary gland, lactation, 229

Baby milk, formulae, vitamins, 521

Bacteria, see individual bacteria and types

Bacteriostasis, whey, oxygen radicals, role, effect of radical scavengers, 149

Calving interval, lactation, milk yield, 1

Camel, milk, casein micelles, size, 303

Casein, curd, particle size, Ca content, effect of $\mathrm{pH}$, temperature, 419

micelles, calcium phosphate, structure, 267

chromatography, 391

size, camel milk, 303

proteolysis, various proteinases, 101

$\boldsymbol{\beta}$-Casein, human milk, 239

$\boldsymbol{\kappa}$-Casein, $\beta$-lactoglobulin, heat induced interaction, syneresis, 159

cheesemaking, genetic variants, 429

$\boldsymbol{\beta}$-Casomorphins, milk, incubated, bacteria, 139

Centrifuge(s), fractionation, homogenized milk, 7

Cheddar cheese, flavour, proteolysis, high temperature storage, 565

making,

disinfectant residues, effect on starters, 287

encapsulated proteinase, 183

recombinant calf chymosin, 281

using UF-concentrated milk, pretreated, 555

organoleptic properties, effect of disinfectant residues, 287

Cheesemaking, see also Cheddar cheese

$\kappa$-casein, $\beta$-lactoglobulin, genetic variants, 429

deproteinated cheese whey, anaerobic digestion, 457

Chelators, extracellular proteinase, Pseudomonas fluorescens $32 \mathrm{~A}$, inhibition, 91

Cheshire cheese, diets fed to cows, effect of, 573,587 variation cheese milk, 573,587

Chromatography, casein micelles, particles, homogenized, milk, 391

Chymosin, see Rennin

Citrate and lactoferrin, milk, effect of ACTH and oxytocin, 379

Coagulation, milk proteins, heated, stability, formaldehyde, 65

UHT, dissociation micellar $\kappa$-casein, 529 rennet, effect of diet, 33,41

Dehydrogenases, NADP-linked, milk, 501

Diet, composition, properties, milk, composition, quality, Cheshire cheese, 573,587

milk-yield, -composition, 17, 33

seasonal change, lipolysis, milk separation, 255

Disinfectants, residues, effect on starters, organoleptic properties, cheese, 287

Enzymes, see individual enzymes
Escherichia coli, penetrability, teat duct, 361 recombinant rennin, Cheddar cheesemaking, 281

Fibronectin, properties, colostrum, milk, 507

Flavour, ghee, ripening cream, Streptococcus lactis subsp. diacetilactis, 547

milk, grass or legume diets, 33

Formaldehyde, heat stability, milk, 65

Fouling, whey proteins, stainless steel, high temperatures, 213

Ghee, flavour, ripening cream, Streptococcus lactis subsp. diacetilactis, $\mathbf{5 4 7}$

Glucose, uptake, mammary gland, 229

Goat(s), milk, micellar calcium phosphate, structure, 267

rennet curd, syneresis, measurement, 209

Gurr, M. I. Prof., C.V., 489

Heat stability, see Coagulation, milk proteins, heated

Heat treatment, milk, lactulose production, 409 urea/protein interaction, 401

Homogenized milk, centrifugal fractionation, 539 chromatography, 391

Hormones, see individual hormones

Human milk, $\beta$-casein, 239

$\beta$-lactoglobulin, 249

micellar calcium phosphate, structure, 267

Immune defences, mucosal surfaces, ruminants (review), 599

Kariesh cheese, microstructure, 299

Kefir, fermented milks, 451

Keratin, teat duct, reaming, penetrability, Escherichia coli, 361

Lactase (Streptococcus thermophilus), thermostability, milk, sweet whey, 439

Lactation, amino acids, glucose, uptake, mammary gland, 229

milk yield, calving interval, effect of, 1

stage, lipase, lipolysis, $\mathbf{5 5}$

carbon or Staphylococcus aureus from mammary gland lumen to lymph nodes, 491

Lactoferrin and citrate, milk, effect of ACTH and oxytocin, 379

$\boldsymbol{\beta}$-Lactoglobulin,

$\kappa$-casein, heat induced interaction, syneresis, 159 cheesemaking, genetic variants, 429

human milk, 249

Lactoperoxidase system, lipoprotein lipase, lipolysis, milk, 513

Lactulose, heated milks, 275

lactose, epimerization, heat treatment, milk, 409

Leucocytes, proteinase, proteolysis, casein, 101

Lipases, milk, lactation stage, milking time, 55

lipoprotein, effect of lactoperoxidase system, 513 


\section{Index of Subjects}

Lipases (cont.)

separation, processing temperature, seasonal change in diet, effect of, 255

Lipolysis, milk, lactation stage, milking time, relationship, 55

lactoperoxidase system, inhibition, lipoprotein lipase, 513

mechanical separation, effect of temperature, diet, 255

Liposomes, encapsulated proteinase, Cheddar cheesemaking, 183

Lymph nodes, receipt carbon or Staphylococcus aureus from mammary gland, $\mathbf{4 9 1}$

Lysin, $\phi \mathrm{C} 2(\mathrm{~W})$ phage-infected cells, Streptococcus lactis, 113,123

Mammary gland, amino acids, glucose uptake, lactation sheep, 229

lumen, carbon or Staphylococcus aureus transport to lymph nodes, 491

Methane, from deproteinated whey, 457

Milk, bacteriological quality, effect of method of teat drying, 355

fermented, based on kefir, 451

fibronectin, 507

lactase, thermostability, 439

$\mathrm{N}^{\dagger}$ ADP-linked dehydrogenases, 2

${ }^{31} \mathrm{P}$ nuclear magnetic resonance spectrum, 47

streptomycin residues, test, $\mathbf{5 9 5}$

Milk composition, Cheshire cheese, quality, composition, 573, 587

diets fed to cows, effect of $17,33,41,573,587$

oestrus, 9

Milk fat, breakdown, see Lipolysis

globule, membrane, isolation, properties, 309

Milk production, grazed temperate grassland (review), 313

Milk proteins, see also Whey proteins

breakdown, see Proteolysis

plasmin activity, proteose-peptone content, 369

urea interaction, heat treatment, milk, 401

Milk yield, calving interval, effect of, 1

diets, effect of, 17

oestrus, 9

Milking time, lipase activity, lipolysis, 55

National Institute for Research in Dairying, 345

Oestrus, milk-yield, -composition, 9

Oxytocin treatment, milk, effect on citrate; lactoferrin concentrations, 379

${ }^{31} \mathrm{P}$ nuclear magnetic resonance spectrum, milk, 47

Pasteurization, UHT, lactulose concentration, 275

Pasteurized milk, storage, deterioration (review) 469

pH-dependent, dissociation of micellar, $\kappa$-casein, 529

Pig, milk, micellar calcium phosphate, structure, 267

Plasmin, proteinase, proteolysis, casein, 101 proteose-peptone content, milk, 369

Proteinase, encapsulated in liposomes, Cheddar cheesemaking, 183

natural, leucocyte, bacterial, proteolysis, casein, 101

Pseudomonas AFT 21, heat stable, 77

Ps. fluorescens 32A, inhibition, chelators, 91

Proteolysis, casein, leucocyte, bacterial, natural proteinases, 101
Cheddar cheese ripening, $\mathbf{5 6 5}$

Pseudomonas AFT 21, heat stable proteinases, 77

Ps. fluorescens 32A, proteinases, inhibition, chelators, 91

Psychrotrophic bacteria, incubated, milk, $\beta$-casomorphins, release, 139

proteinase, proteolysis, casein, 101

Rabbit, milk, micellar calcium phosphate, structure 267

Rat, milk, micellar calcium phosphate, structure, 267

Rennet, coagulation, milk, effect of diet, 33, 41

curd, syneresis, measurement, 209

Rennin, recombinant, cheesemaking, comparison rennet, 281

Ryegrass, grazed, milk-yield, -composition, properties, 17, 33, 41

Serotonin, motility, teat muscles, 347

Sheep, lactating, amino acids, glucose, uptake, mammary gland, 229

Silica-based ion-exchange medium, whey protein fractionation, 167

Skim milk, heated, viscosity, 223

Soft cheese, W. African, chemical preservation, 189

Sorbic, propionic acids, soft cheese preservation, 189

Staphylococcus aureus, oxygen toxicity, effect of radical scavengers, whey, 149

Starters, Cheddar cheese, effect of disinfectant residues, 287

Storage, milk, pasteurized, deterioration (review), 469

Streptococcus agalactiae, contamination, teat, 355

oxygen toxicity, effect of radical scavengers, whey, 149

Str. lactis, $\phi \mathrm{C} 2(\mathrm{~W})$ phage, lysin production, 113,123

Str. lactis subsp. diacetilactis, ripening cream, ghee, flavour, 547

Streptococcus thermophilus, lactase, thermostability, milk, sweet whey, 439

Streptomycin, residues, milk, 595

Syneresis, goat milk rennet curd, measurement, 209

heated milk, $\beta$-lactoglobulin, $\alpha$-casein interaction, 159

Teat, drying, disinfectant cloths, 355

duct, ke'atin removal, Escherichia coli endotoxin, penetrability, 361

muscles, motility, effect of serotonin, 347

Triacyl-sn-glycerols, plasma, milk, rat, rabbit, 219

UItrafiltration, milk, Cheddar cheesemaking, 555

Urea, protein interaction, heat treatment, milk, 401

Viscosity, heated skim milk, 223

Vitamins, baby milk formulae, $\mathbf{5 2 1}$

Whey, bacteriostatic effect, oxygen radicals, effect of radical scavengers, 149

lactase, thermostability, 439

proteins, fouling, stainless steel, 213

recovery, anaerobic digestion, 457

silica ion-exchange medium, 167

White clover, grazed, milk-yield, -composition properties, 17, 33, 41

Yogurt, nutritional value, 197 


\section{Index of Authors}

Abd El-SalaM, M. H., 299

Abrahamsen, R. K., 209

Ahrn É, L., 55, 513

ALI, M. Z., 303

Allen, J. C., 469

ANAND, S. K., 595

ANDerson, M., 33, 41, 255, 573, 587

Andrews, G. R., 275

AngaL, S., 281

Annan, W. D., 401

ARkins, R., 287

Aston, J. W., 565

Austin, A. R., 17

Aworh, O. C., 189

Bancroft, H. J., 197

BeEver, D. E., 17

BetTon, P. S., 47

Berman, D. T., 491

BISHOP, D. R., 521

BJöRCK, L., 55, 513

Bramley, A. J., 355, 361

BREMNER, K., 9

BRIGNON, G., 239, 249

Britz, T. J., 457

Burveniah, C., 347

Cammell, S. B., 17

Carolan, T., 401

Castbera, H. B., 213

Chenseman, G. C., 345

Cholette, H., 91

Christie, W. W., 219

Chtourou, A., 239, 249

Cole, W. M., 451

Crawford, R. J. M., 113, 123

Dalaleish, D. G., 391, 539

De HaAst, J., 457

Dhanoa, M. S., 17

Dils, R. R., 489

Dulley, J. R., 565

Dunsmore, D. G., 287

DURWARD, I. G., 565

Egounlety, M., 189

Evans, R. T., 17

Fell, L. R., 379

Fleet, I. R., 229

Ford, G. D., 41, 573, 587

Fox, P. F., 65, 77, 529

Giles, J. E., 565

Grandison, A. S., 33, 41, 573, 587

Green, M. L., 281, 555

Greenberg, N. A., 439

Greig, B. D., 409

Grieve, P. A., 101

GriQor, M. R., 501

GurR, M. I., 346
Haines, M. J., 17

HALL, R. J., 159

HaMel, U., 139

HaNSSON, B., 429

HartmanN, P. E., 501

Hasnain, S. S., 267

Hayashi, M., 507

Hegg, P.-O., 213

HewitT, D., 197

Higas, T. M., 355

Holt, C., 267

Horne, D. S., 391

Horrell, R. I., 9

Hukins, D. W. L., 267

Husband, A. J., 599

IrLAM, J. C., 267

JABLONKA, M. S., 419

JosepH, G., 469

Kielwein, G., 139

Kilgour, R., 9

KING, J. S., 183

Kitchen, B. J., 101

LANGLEY, K. R., 223

LAW, B. A., 183

LeAVER, J. D., 313

Linklater, P. M., 159

LOWE, P. A., 281

LUNDH, G., 213

LYON-SMTTH, P., 573

LySTER, R. L. J., 47

McKellar, R. C., 91

Mackinlay, A. G., 159

Mckinnon, C. H., 355

Macmillan, K. L., 9

Mahoney, R. R., 439

MAKIN, D., 287

Manning, D. J., 33

Manson, W., 401

Marshall, V. M., 451

Marston, F. A. O., 281

Mattila, T., 149

Mepham, T. B., 229

Millard, D., 41

Mullan, W. M. A., 113, 123

Munro, P. A., 419

Needs, E. C., 255

Neweld, L., 573, 587

NiLSEN, K. O., 209

Novello, J. C., 457

OMAR, M. M., 299

Payne, G. A., 409

Payne, S. J., 255

Pearse, M. J., 159

Peeters, G., 347

Pettersson, H.-E., 429 


\section{Index of Authors}

Ribadeau-Dumas, B., 239, 249

RtchaRds, C. P., 47

Ripout, E. A., 255

Robinson, R. K., 303

Robson, E. W., 391, 539

SATO, T. N., 507

SchaAR, J., 369, 429

SChenkman, D. I., 491

Schultze, W. D., 361

ScotT, K. J., 521

Sheldrake, R. F., 599

Singh, H., 65, 529

Sivgh, R. S., 595

Skudder, P. J., 167
Srinivasan, R, A., 547

Stepaniak, L., 77

Temple, D. M., 223

Teschemacher, H., 139

Thomas, A. S. A., 379

Thomson, D. J., 17, 33

Vandeputte-Van Messom, G., 347

VERWEY, E. W., 457

Walstra, P., 309

WILDER, T., 439

Woop, P. D. P., 1

YADAV, J. S., 547

YADAVALLI, R. K., 595

YANDELL, B. S., 491 


\section{Journal of D A I R Y \\ RESEAR C H}

EDITED BY

M. ELISABETH SHARPE, Ph.D., D.Sc., F.I.BIol. AFRC Food Research Institute,

Shinfield, Reading RG2 9AT

W. MANSON, Рh.D.

Hannah Research Institute, Ayr KA6 5HL

Assistant Editors
A.T. ANDREWS, M.A., D.Phil., D.Sc.
B. F. BONE, B.A., A.L.A., M.I.Inf.Sc.
E. W. EVANS, B.Sc., Ph.D.

\section{Editorial Assistants}

DOROTHY SKIDMORE

B. GILLIAN DAY, B.Se.

Secretary

L. C. FITZGERALD

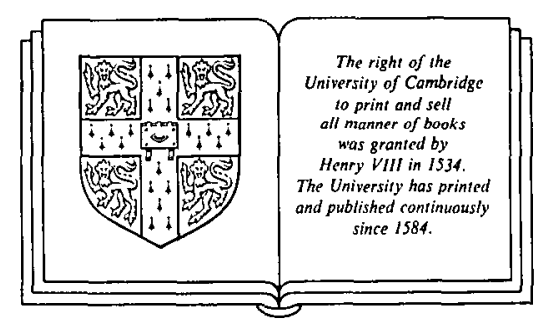

V OLUME 52, 1985

CAMBRIDGE UNIVERSITY PRESS 
PUBLISHED BY

THE SYNDICS OF THE CAMBRIDGE UNIVERSITY PRESS

The Pitt Building, Trumpington Street, Cambridge CB2 1RP

32 East 57th Street, New York, NY 10022

10 Stamford Road, Oakleigh, Melbourne 3166 Australia

(C) Proprietors of The Journal of Dairy Research 1985 


\section{Contents}

No. 1 (February 1985)

PAGE

Importance of the calving interval to milk yield in the following lactation of British Friesian cows. P. D. P. Wood

Changes in milk yield and composition at oestrus in dairy cows. R. I. HorRELL, K. L. Macmillan, R. Kilgour and K. Bremner

Yield and composition of milk from Friesian cows grazing either perennial ryegrass or white clover in early lactation. D. J. Thomson, D. E. Beever, M. J. Harnes, S. B. Cammell, R. T. Evans, M. S. Dhanoa and A. R. Austin .

Chemical composition, rennet coagulation properties and flavour of milks from cows grazing ryegrass or white clover. A. S. Grandison, D. J. Manning, D. J. Thomson and M. Anderson

Interrelationships of chemical composition and coagulating properties of renneted milks from dairy cows grazing ryegrass or white clover. A. S. Grandison, G. D. Ford, D. Mullard and M. Anderson

The ${ }^{31} \mathrm{P}$ nuclear magnetic resonance spectrum of cows' milk. P. S. BELTon, R. L. J. Lyster and C. P. Richards

Lipolysis and the distribution of lipase activity in bovine milk in relation to stage of lactation and time of milking. L. AHRN É and L. BJörCK . ·

Heat stability of milk: the mechanism of stabilization by formaldehyde. H. SINGH and P. F. Fox.

Isolation and characterization of heat stable proteinases from Pseudomonas isolate AFT 21. L. Stepaniak and P. F. Fox .

Inhibition by chelating agents of the formation of active extracellular proteinase by Pseudomonas fuorescens 32A. R. C. MCKELlaR and H. Cholette

Proteolysis in milk: the significance of proteinases originating from milk leucocytes and a comparison of the action of leucocyte, bacterial and natural milk proteinases on casein. P. A. Grieve and B. J. KitcheN

Lysin production by $\phi \mathrm{C} 2(\mathrm{~W})$, a prolate phage for Streptococcus lactis $\mathrm{C} 2$. W. M. A. Mullan and R. J. M. Crawford

Partial purification and some properties of $\phi \mathrm{C} 2(\mathrm{~W})$ lysin, a lytic enzyme produced by phage-infected cells of Streptococcus lactis C2. W. M. A. Mullan and R. J. M. Crawford

$\beta$-Casomorphin immunoreactive materials in cows' milk incubated with various bacterial species. U. Hamel, G. Kielwein and H. Teschemacher.

Role of oxygen radicals in the bacteriostatic effect of whey and production of bacterial growth by free radical scavengers. T. MATTILA . 
Effect of heat induced interaction between $\beta$-lactoglobulin and $\kappa$-casein on syneresis. M. J. Pearse, P. M. Linklater, R. J. Hall and A. G. MACKINLEY

Evaluation of a porous silica-based ion-exchange medium for the production of protein fractions from rennet- and acid-whey. P. J. SKUDdER . .

Use of liposomes for proteinase addition to Cheddar cheese. B. A. LAw and J. S. KING

Preservation of West African soft cheese by chemical treatment. O. C. Aworh and M. Egounlety.

Nutritional value of yogurt. D. HewitT and H. J. BANCroft

Difficulties in measuring the syneresis of goat milk rennet curd by dilution of an added tracer. K. O. Nilsen and R. K. Abrahamsen .

Fouling of whey proteins on stainless steel at different temperatures. P.-O. Hegg, H. B. Castberg and G. Lundh .

Structure of the triacyl-sn-glycerols in the plasma and milk of the rat and rabbit. W. W. Christie

Viscosity of heated skim milk. K. R. Langley and D. M. Temple

Mammary uptake of amino acids and glucose throughout lactation in Friesland sheep. I. R. Fleet and T. B. Mepham

Quantification of $\beta$-casein in human milk. A. Chtourou, G. Brignon and B. Ribadeau-Dumas

Does $\beta$-lactoglobulin occur in human milk? G. Brianon, A. Chtourou and B. Ribadeau-Dumas

Influence of processing temperature and seasonal change in diet on lipase activity and lipolysis during the mechanical separation of bovine milk. E. C. Needs, M. Anderson, S. J. Payne and E. A. Ridout .

Comparison of the structure of micellar calcium phosphate in milk from six species by extended $\mathrm{X}$-ray absorption fine structure spectroscopy. J. C. Irlam, C. Hol't, S. S. Hasnain and D. W. L. Hukins

Determining the energy of activation for the formation of lactulose in heated milks. G. R. ANDREws

Cheddar cheesemaking with recombinant calf chymosin synthesized in Escherichia coli. M. L. Green, S. Angal, P. A. Lowe and F. A. O. Marston .

Effect of residues of five disinfectants in milk on acid production by strains of lactic starters used for Cheddar cheesemaking and on organoleptic properties of the cheese. D. G. Dunsmore, D. Makin and R. Arkins

Microstructure of Kariesh cheese. M. H. Abd El-Salam and M. M. OMaR

Size distribution of casein micelles in camels' milk. M. Z. ALI and R. K. Robinson 


\section{Contents}

Some comments on the isolation of fat globule membrane material.

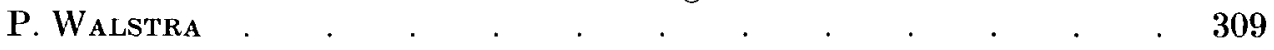

Milk production from grazed temperate grassland. J. D. LEaver . . . 313

$$
\text { No. } 3 \text { (August 1985) }
$$

Foreword. G. C. Cheeseman and M. I. Gurr.

Effect of serotonin on the motility of smooth muscles in teats of lactating cows. G. Vandeputte-van Messom, C. Burvenich and G. Peeters

An examination of teat drying with disinfectant impregnated cloths on the bacteriological quality of milk and on the transfer of Streptococcus agalactiae before milking. C. H. McKinnon, T. M. Higas and A. J. BRAMLEY

Effect of reaming the papillary duct of cows' teats on keratin removal and penetrability of the duct to implanted Escherichia coli endotoxin. W. D. Schultze and A. J. Bramley

Plasmin activity and proteose-peptone content of individual milks. J. SCHAAR

Effect of ACTH and oxytocin treatment on lactoferrin and citrate in cows' milk. A. S. A. Thомas and L. R. Fell

Chromatography of casein micelles and particles from homogenized milk on columns of controlled pore glass and large pore silica gel. E. RoBson, D. S. Horne and D. G. Dalgleish .

Products of the heat-promoted reaction between urea and the protein fraction of bovine milk. W. Manson, T. Carolan and W. D. Annan .

Epimerization of lactose to free lactulose in heated model milk solutions. B. D. Greig and G. A. Payne.

Particle size distribution and calcium content of batch-precipitated acid casein curd: effect of precipitation temperature and pH. M. S. JABLONKA and P. A. Munro

Effects of genetic variants of $\kappa$-casein and $\beta$-lactoglobulin on cheesemaking. J. SchaAr, B. Hansson and H.-E. PetTersson

Studies on the thermostability of lactase (Streptococcus thermophilus) in milk and sweet whey. N. A. Greenberg, T. Wilder and R. R. Mahoney

Methods for making kefir and fermented milks based on kefir. V. M. MarshaLL and W. M. CoLE

Anaerobic digestion of deproteinated cheese whey. J. DE HAAst, T. J. BRITz, J. C. Novello and E. W. Verwey .

Deterioration of pasteurized milk on storage. J. C. Allen and G. Joseph 
No. 4 (November 1985)

Professor M. I. Gurr, B.Sc., Ph.D. 489

Effect of stage of lactation on transport of colloidal carbon or Staphylococcus aureus from the mammary gland lumen to lymph nodes in guinea pigs. D. I. Schenkman, D. T. Berman and B. S. YANDelL

NADP-linked dehydrogenases in secreted milk. M. R. GRIGor and P. E. HartmanN

Purification and characterization of bovine milk fibronectin. T. N. SATo and M. HaYASHI

Effect of the lactoperoxidase system on lipoprotein lipase activity and lipolysis in milk. L. AHRNÉ and L. BJörCK

Nutrient content of milk and milk products: water soluble vitamins in baby milk formulae. K. J. ScotT and D. R. Bishop.

Heat stability of milk; $\mathrm{pH}$-dependent dissociation of micellar $\kappa$-casein on heating milk at ultra high temperatures. H. SingH and P. F. Fox .

Centrifugal fractionation of homogenized milks. D. G. DALGLEISH and E. W. Robson.

Effect of ripening cream with Streptococcus lactis subsp. diacetilactis on the flavour of ghee (clarified butterfat). J. S. Yadav and R. A. SRInivasan .

Effect of milk pretreatment and making conditions on the properties of Cheddar cheese from milk concentrated by ultrafiltration. M. L. Green .

Effect of elevated ripening temperatures on proteolysis and flavour development in Cheddar cheese. J. W. Aston, J. E. Giles, I. G. Durward and J. R. Dulley .

Effect of variation in the composition of milk supply on the composition and quality of farmhouse Cheshire cheese. A. S. Grandison, M. Anderson, G. D. Ford, L. Newell and P. Lyon-SMith .

Interrelationships between the diet fed to cows, composition and properties of milk and composition and quality of Cheshire cheese from farmhouse manufacturers. A. S. Grandison, M. Anderson, G. D. Ford and L. NewEll . . . . . . . . . . .

Diffusion test for the detection of streptomycin residues in milk. R. K. Yadavalli, R. S. Singh and S. K. Anand

Immune defences at mucosal surfaces in ruminants. R. F. SHELdRAKE and A. J. Husband 


\section{DIRECTIONS TO CONTRIBUTORS}

\section{GENERAL}

Two copies of manuscripts should be sent to Dr M. E. Sharpe (The Journal of Dairy Research), Food Research Institute, Reading, Shinfield, Reading, RG2 9AT, U.K. Submission of a paper will be held to imply that it reports unpublished original work, that it is not under consideration for publication elsewhere, and that if accepted for the Journal it will not be published elsewhere in any language, without the consent of the Editors.

\section{FORM OF PAPERS}

The author should follow these directions carefully, and consult a current issue of the Journal for guidance on details of typographical and other conventions.

Every paper should be headed with its title, the names and initials of the authors (each author supplying one given name) and the name and address of the laboratory where the work was done.

Papers should be in English, using the spelling of the Shorter Oxford English Dictionary. They should be typed with double spacing, on one side only of the sheets, and with ample margins for editorial annotations.

Papers should in general be divided into the following parts in the order indicated: (a) Summary, brief and self-contained; (b) Introductory paragraphs, briefly explaining the object of the work but without giving an extensive account of the literature; $(c)$ Experimental or Materials and Methods; $(d)$ Results; $(e)$ Discussion and Conclusions; $(f)$ Acknowledgements, without a heading; $(g)$ References. With some types of material headings other than $(c),(d)$ and $(e)$ may be preferable.

The use of footnotes should be avoided if possible. Underlining should be used only to indicate italics. Proper nouns, including trade names, should be given a capital initial letter. Manufacturers or suppliers of materials and equipment, with their addresses, should be given. The typescript should carry the name and address of the person to whom the proofs are to be sent, and give a shortened version of the paper's title, not exceeding 45 letters and spaces, suitable for a running title in the Journal.

\section{TABLES}

Tables should be numbered and should carry headings describing their content. They should be comprehensible without reference to the text. They should be typed on separate sheets and their approximate positions in the text indicated. To minimize the cost of printing, the number and size of tables should be kept to an absolute minimum.

\section{ILLUSTRATIONS}

Line drawings and photographs, which must be originals, should be numbered as Figures in Arabic numerals. Drawings should be in Indian ink, on Bristol board or cartridge paper. However, a technique which may be more convenient to authors is to use a doublesized folded piece of tracing paper, or translucent graph paper with the drawing on one half and the other half acting as a flyleaf. There should be no lettering or numerals on the drawing itself.

Attached to every figure there should be a translucent flyleaf cover on the outside of which should be written legibly: (a) title of paper and name of author; $(b)$ figure number; $(c)$ the figures and lettering, which are intended to appear on the finished block, in the correct positions relative to the drawing underneath. Each paper should have a separate typed sheet listing figure numbers with their legends, and the approximate positions of illustrations should be indicated in the text.

The photographs and diagrams should be about twice the size of the finished block and not larger overall than the sheets on which the paper itself is typed. For a figure measuring $250 \mathrm{~mm} \times 150 \mathrm{~mm}$ all lines, axes and curves should be $0.4 \mathrm{~mm}$ thick, thus Graph symbols in order of preference are $\bigcirc, \Delta \boldsymbol{\Delta}$, $\square$, $\times+$, and for a $250 \mathrm{~mm} \times 150 \mathrm{~mm}$ graph the circles should be $3 \mathrm{~mm}$ in diam. The triangles should be equilateral of $3 \mathrm{~mm}$ side, and the squares also of $3 \mathrm{~mm}$ side. The crosses should have lines $3 \mathrm{~mm}$ long at right angles. Scale marks on the axes should be on the inner side of each axis and should be $3 \mathrm{~mm}$ long.

\section{SHORT COMMUNICATIONS}

Short communications or notes of not more than 2500 words or the equivalent space in print and without a summary will also be published.

\section{REFERENCES}

In the text, references should be quoted by whichever of the following ways is appropriate; Arnold \& Barnard (1900); Arnold \& Barnard (1900a); Arnold \& Barnard $(1900 a, b) ;($ Arnold et al. 1900). Give both names for two authors. For three or more authors give the first name $e t$ al. on all occasions, adding $a, b$, etc., to the date if there is any ambiguity.

References should be listed alphabetically at the end of the paper. Titles of journals should be given in full, authors' names should be in caps and their initials included. Each reference should be punctuated and set out thus: ARNOLD, T. B., BARNARD, R. N. \& COMPOUND, P. J. 1900 Title of paper. Journal of Dairy Research 18 158-165, and references to books should include names of authors, year of publication, title, names of editors, town of publication and name of publisher in that order, thus: ARNOLD, T. B. 1900 In Dairying (Ed. R. W. Brown) vol 1, pp. 5-11. London: Brown and Chester.

It is the duty of the author to check all references.

\section{UNITS, SYMBOLS AND ABBREVIATIONS}

SI units must be used, as explained in British Standards Institution publication BS 5555: 1981 (Specification for SI units and recommendations for the use of their multiples and of certain other units). Until SI units are widely understood, it is permissible to give the equivalent value in other units in parenthesis. Symbols and abbreviations used are those of British Standard 5775 Specification for Quantities, Units and Symbols.

\section{DESCRIPTIONS OF SOLUTIONS}

Normality and molarity should be indicated thus; $\mathrm{N}-\mathrm{HCl}, 0 \cdot 1 \mathrm{M}-\mathrm{NaH}_{2} \mathrm{PO}_{4}$. The term ' $\%$ ' means $\mathrm{g} / 100 \mathrm{~g}$ solution. For $\mathrm{ml} / 100 \mathrm{ml}$ solution the term ' $\%(\mathrm{v} / \mathrm{v})$ ' should be used and for $\mathrm{g} / 100 \mathrm{ml}$ solution the correct abbreviation is ' $\%(w / v)$ '.

\section{OFFPRINTS}

Order forms giving quotations for offprints are sent to authors with their proofs. 


\section{CONTENTS}

Professor M. I. Gurr, B.Sc., Ph.D.

page 489

ORIGINAL ARTICLES

Effect of stage of lactation on transport of colloidal carbon or

Staphylococcus aureus from the mammary gland lumen to lymph nodes

in guinea pigs

D. I. SCHENKMAN, D. T. BERMAN and B. S. YANDELL

$491-500$

NADP-linked dehydrogenases in secreted milk

M. R. GRIGOR and P. E. HARTMANN

$501-506$

Purification and characterization of bovine milk fibronectin

T. N. SATO and M. HAYASHI

$507-511$

Effect of the lactoperoxidase system on lipoprotein lipase activity and lipolysis in milk

L. AHRNÉ and L. BJÖRCK

$513-520$

Nutrient content of milk and milk products: water soluble vitamins in baby milk formulae

K. J. SCOTT and D. R. BISHOP

$521-528$

Heat stability of milk: pH-dependent dissociation of micellar $\kappa$-casein

on heating milk at ultra high temperatures

H. SINGH and P. F. FOX

Centrifugal fractionation of homogenized milks

D. G. DALGLEISH and E. W. ROBSON

$539-546$

Effect of ripening cream with Streptococcus lactis subsp. diacetilactis on the flavour of ghee (clarified butterfat)

J. S. YADAV and R. A. SRINIVASAN

$547-553$

Effect of milk pretreatment and making conditions on the properties

of Cheddar cheese from milk concentrated by ultrafiltration

M. L. GREEN

$555-564$

Effect of elevated ripening temperatures on proteolysis and flavour

development in Cheddar cheese

J. W. ASTON, J. E. GILES, I. G. DURWARD and J. R. DULLEY

$565-572$

Effect of variation in the composition of milk supply on the composition and quality of farmhouse Cheshire cheese

A. S. GRANDISON, M. ANDERSON, G. D. FORD, L. NEWELL and

P. LYON-SMITH

$573-586$

Interrelationships between the diet fed to cows, composition and

properties of milk and composition and quality of Cheshire cheese from farmhouse manufacturers

A. S. GRANDISON, M. ANDERSON, G. D. FORD and L. NEWELL

$587-593$

SHORT COMMUNICATION

Diffusion test for the detection of streptomycin residues in milk

R. K. YADAVALLI, R. S. SINGH and S. K. ANAND

$595-597$

REVIEW ARTICLE

Immune defences at mucosal surfaces in ruminants

R. F. SHELDRAKE and A. J. HUSBAND 